\title{
RENEWABLE HYDROGEN UTILISATION FOR THE PRODUCTION OF METHANOL
}

\author{
P. Galindo Cifre and O. Badr \\ Process Systems Engineering Group, \\ School of Engineering, Cranfield University, \\ Cranfield, Bedfordshire MK43 OAL, UK
}

\begin{abstract}
Electrolytic hydrogen production is an efficient way of storing renewable-energy generated electricity and securing the contribution of renewables in future electricity supply. The use of this hydrogen for the production of methanol results in a liquid fuel that can be utilised directly with minor changes in the existing infrastructure. To utilise the renewable-generated hydrogen for the production of renewable methanol, a sustainable carbon source is needed. This carbon can be provided by biomass or $\mathrm{CO}_{2}$ in the flue gases of fossil fuel-fired power stations, cement factories, fermentation processes and water purification plants.

Methanol production pathways via biomass gasification and $\mathrm{CO}_{2}$ recovery from the flue gasses of a fossil fuel-fired power station have been reviewed in this study. The cost of methanol production from biomass was found to lie in the range of $300-400 € /$ tonne of methanol and the production cost of $\mathrm{CO}_{2}$-based methanol was between 500 and 600 $€ /$ tonne. Despite the higher production costs compared with the methanol produced by conventional natural gas reforming (i.e. 100 to $200 € /$ tonne, aided by the low current price of natural gas), these new processes incorporate environmentally beneficial aspects that have to be taken into account.
\end{abstract}

Keywords:

Renewable electricity, biomass, $\mathrm{CO}_{2}$, energy storage, methanol, renewable fuels.

* Corresponding author:

Tel. $\quad+44(0) 1234754781$

Fax $\quad+44(0) 1234754685$

e-mail o.dadr@cranfield.ac.uk

\section{INTRODUCTION}

Renewable energy sources are the second largest contributor to global electricity production. They accounted for $19 \%$ of power generation in 2000 , compared with $39 \%$ from coal-fired power plants, $17 \%$ from each of nuclear and natural gas-fired power plants and $8 \%$ from oil-fired power plants [1]. 92\% of the electricity generated from renewable energy sources comes from large-scale hydropower stations plants. Biomass utilisation schemes contribute $5 \%$ towards renewable electricity, with the remaining $3 \%$ being produced by the utilisation of new renewable sources, i.e. geothermal, solar, wind, wave and tidal energy [1]. 
There are many drawbacks, however, in the utilisation of new renewable energy sources for electricity generation, including [2]:

- Requirement of large installation because of low energy density

- Low controllability and endurance because of the frequent fluctuations

- Quantitative and temporal mismatches between demand and supply

To resolve the problems of dispatching large amounts of variable, intermittent and largely unpredictable renewable electricity to remote areas of a conventional electrical grid, an alternative efficient means of storing and transporting the energy will be needed.

Energy storage in the form of chemical compounds is likely to play an important and increasing role. Hydrogen is most promising storage medium due to its excellent energy content to weight ratio and the high conversion efficiencies achievable in its production (electrolysis) and use (fuel cells). Electrolysers can operate successfully at variable power supply with a typical conversion efficiency of $>85 \%$ [3]. Electrolysers can be placed near the source of the renewable-energy generated electricity, avoiding, therefore, the need for transmission line upgrades and preventing flows of power back up the distribution network. However, hydrogen produced from water electrolysis is relatively expensive due to the high capital cost of the electrolysis cells. Gaseous hydrogen also has the disadvantage of low energy density. The introduction of gaseous hydrogen as an energy carrier requires a complete technical and organisational infrastructure for storage, transport, distribution and use.

Liquid energy carriers (i.e. liquid fuels) have great advantages of high energy density for storage and transportation, and the ease of handling. Despite the associated conversion efficiency, the conversion of gaseous hydrogen to liquid methanol results in a more convenient alternative energy carrier that can be handled by the existing infrastructure [4].

\section{USE OF METHANOL}

Methanol (methyl alcohol, $\mathrm{CH}_{3} \mathrm{OH}$ or simply $\mathrm{MeOH}$ ) may be used as:

- a hydrogen carrier;

- a fuel; or

- a feedstock for chemical synthesis.

Methanol is the simplest liquid organic hydrogen carrier. It can be viewed either as a hydrogen storage compound or directly as a fuel. In methanol each $\mathrm{m}^{3}$ of carbon combines with $1,100 \mathrm{~m}^{3}$ of hydrogen. In contrast, a maximum amount of $800 \mathrm{~m}^{3}$ of liquefied hydrogen can be theoretically stored in a $1 \mathrm{~m}^{3}$ tank at $-253^{\circ} \mathrm{C}$ [5]. Methanol is specially favoured for future application in fuel cell-powered vehicles as an onboard hydrogen storage medium. This is mainly due to the fact that it can be broken down relatively easy, with the use of steam, into carbon dioxide and hydrogen, from which the fuel cell extracts the $\mathrm{H}_{2}$ fuel [6].

Biofuels (i.e. alcohols and biodiesels) and other renewable fuels offer clear advantages in terms of security of supply, reducing the dependency on imported petroleum products and technical and environmental performance. Biofuels can be manufactured via numerous production options. Because of its physical and chemical characteristics, 
methanol proved to be an attractive automotive fuel $[7,8]$. Methanol can be mixed with conventional petrol without any technical modifications having to be made to the vehicle fleet. Most methanol-fuelled vehicles use M85, a mixture of $85 \%$ of methanol and $15 \%$ of unleaded gasoline. Biodiesel is obtained by transesterification of vegetable oils (triglycerides) with methanol. Biodiesel could be used without any major technical problems to replace mineral diesel.

$\mathrm{MeOH}$ can be used in direct methanol fuel cells, where there is no need for an onboard reformer [6]. For the power industry, fuel grade methanol is a clean and efficient alternative fuel for gas turbines [9].

Approximately $70 \%$ of the methanol produced worldwide is used in chemical synthesis [10]. Globally, formaldehyde production consumes 35\% of the methanol produced worldwide. $25 \%$ and $9 \%$ are employed for the production of methyl tertiary-butyl ether (MTBE) and acetic acid, respectively [11].

\section{MANUFACTURING AND PROCESSING OF METHANOL}

Methanol can be synthesized from hydrogen and several carbon-containing feedstocks including:

- carbon concentrated sources, such as natural gas, coal or biomass; and

- carbon dioxide from flue gases of fossil-fuelled power plants or cement factories and the atmosphere.

\subsection{Methanol from Natural Gas}

Currently, more than $75 \%$ of methanol is produced from natural gas [12]. The production is based on three fundamental steps: natural gas reforming in order to produce synthesis gas (syngas), conversion of syngas into crude methanol, and distillation of the crude methanol to achieve the desired purity [12-15]. Table 1 shows main methanol-production technology suppliers and the operating conditions of the methanol synthesis.

\subsection{Methanol from Coal}

The production of methanol from coal involves similar basic processing steps to those involved in its production from natural gas: production of synthesis gas by the gasification of the coal, synthesis of crude methanol and purification of the crude methanol [16-18]. The same methanol reactors as those employed for the natural gasbased process can be used. The syngas produced from coal has, however, lower hydrogen content. The liquid phase methanol $(\mathrm{LPMeOH})$ process is well suited for this application [18]. An important feature of the LPMeOH technology is its potential integration with a combined cycle power plant, i.e. integrated gasification combined 
cycle (IGCC) power generation [18]. With this integration, methanol could be produced from the excess syngas not committed for power generation.

\subsection{Methanol from Biomass}

Methanol can be produced from nearly all organic materials [19]. Biomass consists of carbon which is already available in an enriched form so that this resource is advantageous for the production of synfuels containing carbon [14]. When sustainable biomass production is guaranteed, a $\mathrm{CO}_{2}$-neutral system is formed.

The process for producing methanol from biomass has the same steps as natural gas and coal-based processes: syngas production, methanol synthesis and purification [14,19-22]. However, conventional gasification processes applied to biomass do not always produce a syngas with the quality required for methanol synthesis. In contrast to the biomass gasification process for electricity generation, the synthesis gas for the methanol production should only contain a small proportion of inert gas components. The use of air as a gasification agent, results in a syngas with a high nitrogen content. For methanol synthesis the optimal $\mathrm{H}_{2}: \mathrm{CO}_{2}$ molal ratio in the syngas is $>2$ [19]. The gasification of biomass always results in a gas with a too low $\mathrm{H}_{2}: \mathrm{CO}_{2}$ ratio. Specht et al. [22] studied the two principle methods for adjusting the $\mathrm{H}_{2}: \mathrm{CO}_{2}$ ratio in the derived syngas for methanol production:

- Carbon dioxide separation. Excess carbon in form of $\mathrm{CO}_{2}$ is removed by an acid gas separation process.

- Addition of hydrogen. An adequate amount of $\mathrm{H}_{2}$ is added for $\mathrm{CO}_{2}$ hydrogenation.

\subsection{Methanol from $\mathrm{CO}_{2}$}

Methanol can be produced by heterogeneous catalytic hydrogenation of carbon dioxide $[22,23]$ :

$$
\mathrm{CO}_{2}+3 \mathrm{H}_{2} \rightarrow \mathrm{CH}_{3} \mathrm{OH}+\mathrm{H}_{2} \mathrm{O}
$$

In contrast to the previous processes, the production of methanol from $\mathrm{CO}_{2}$ is only possible via the input of renewably-produced hydrogen. The process is presented in Figure 1. Available sources of $\mathrm{CO}_{2}$ that have been considered include flue gases of fossil fuel-fired power stations, cement factories, fermentation processes and water purification plants, as well as the atmosphere $[6,22,24,25]$.

\section{COMPARISON OF THE PROCESSES}

An evaluation of the processes described in Section 3 was carried out. The criteria adopted for this preliminary screening process are: 
- the amount of carbon dioxide emitted during methanol production and use;

- energy conversion efficiency; and

- estimated costs per tonne of methanol produced.

\section{1. $\mathrm{CO}_{2}$ Emissions}

Lifecycle $\mathrm{CO}_{2}$ emissions (i.e. $\mathrm{CO}_{2}$ emitted over the entire cycle of methanol production and utilisation) were evaluated by Specht and Bandi [19]. These include emissions due to the transport of the feedstock to the synthesis plant, the production process, the transport of the methanol to consumers and the emissions produced when it is used in a passenger car.

The coal-based process has the highest emissions, $3.8 \mathrm{~kg} \mathrm{CO} / \mathrm{kg} \mathrm{MeOH}$. Synthesis from natural gas leads to $\mathrm{CO}_{2}$ emissions of $1.6 \mathrm{~kg} \mathrm{CO} / \mathrm{kg} \mathrm{MeOH}$. In the biomass case, since energy inputs (typically fossil fuel energy) are needed for growing, harvesting and transport of the biomass, and for the delivery of the methanol to consumers, total lifecycle emissions, though very small compared with fossil fuel systems, are not zero (typically, $0.2 \mathrm{~kg} \mathrm{CO} / \mathrm{kg} \mathrm{MeOH}$ ). For the production of methanol from $\mathrm{CO}_{2}$ in the flue gases, lifecycle $\mathrm{CO}_{2}$ emissions are $0.8 \mathrm{~kg} \mathrm{CO} / \mathrm{kg} \mathrm{MeOH.} 50 \%$ of these emissions are due to the $\mathrm{CO}_{2}$ separation process. If atmospheric $\mathrm{CO}_{2}$ is the carbon source for the methanol production, any $\mathrm{CO}_{2}$ emissions as a result of its separation, liquefaction and transport are offset by the $\mathrm{CO}_{2}$ removed from the atmosphere. Consequently, this option is almost $\mathrm{CO}_{2}$-neutral, producing only $0.1 \mathrm{~kg} \mathrm{CO} / \mathrm{kg} \mathrm{MeOH}$.

\subsection{Energy Conversion Efficiencies}

Values of the energy conversion efficiencies for different methanol production processes have been obtained from the studies of Roan et al. [12], Williams et al. [16], Specht and Bandi [19], Specht et al. [22] and Larson and Tingjing [26]. Due to the different definitions of the conversion efficiency employed, degrees of maturity of the individual processes and the capacities of the plants considered, these values should be considered only as first approximations for guidance purposes. The widely-used commercial process of methanol production from natural gas is the most efficient methanol production process, exhibiting a typical value of $75 \%$. This is followed by the coal $(48.5-61.3 \%)$ and the biomass process $(51 \%)$. Both $\mathrm{CO}_{2}$-process options have higher energy demands, mainly due to the separation stage. The energy efficiency for the concentrated $\mathrm{CO}_{2}$ process is about $46 \%$ while that utilising atmospheric $\mathrm{CO}_{2}$ exhibits an efficiency of only $38 \%$. With more advanced technologies, the efficiency can be improved to more than 50 and $44 \%$ respectively [22].

\subsection{Production Costs}

Estimates of the costs of methanol produced from natural gas, coal, biomass and $\mathrm{CO}_{2}$, according to the studies of Roan et al. [12], Williams et al. [16], DoE [18], Specht and Bandi [19] and Specht et al. [22,27], are presented in Figure 2 in 2005 Euros. The selection of system components, the energy demand and the feedstocks are crucial 
$[18,19]$. Many other factors, such as capacity, mode of operation, operating conditions and the desired grade of purity of the final product affect the process economics. Therefore, the values presented in Fig. 2 are only guide figures for preliminary screening.

Methanol from biomass or flue-gas $\mathrm{CO}_{2}$ is at least $2-3$ times more expensive than fossil-fuel based methanol. Methanol can only compete with conventional fossil fuels under an environmental taxation system based on pollutant emissions, particularly those of $\mathrm{CO}_{2}[16,19,21,22,27,28]$. Such a tax will favour mostly the production of methanol from biomass or $\mathrm{CO}_{2}$ in flue gases. Comparing the untaxed renewable methanol costs with taxed gasoline, the cost difference may be rather small [19].

Among the new processes proposed for the employment of renewable hydrogen for the production methanol, the biomass process is the most cost effective. However, the utilisation of flue-gas $\mathrm{CO}_{2}$ for methanol production presents a competitive alternative. Therefore, the processes of methanol production from biomass and from $\mathrm{CO}_{2}$ in flue gases are selected for a more detailed analysis.

\section{METHANOL PRODUCTION FROM BIOMASS}

\subsection{Process Technology}

A biomass-to-methanol plant consists of two main components, a biomass gasifier to convert the feedstock to synthesis gas and a methanol synthesis plant. Biomass gasification technology is at the demonstration to early commercial stage. However, the integration of biomass gasification with methanol production process is only at the R\&D stage and scale-up and environmental issues may prove difficult to overcome [29].

The process proposed by Ouellette et al. [21] is taken as an example for this technology. Apart from the type of biomass used, the gasifier and the methanol reactor, no more details about the process were specified by the authors. Various studies have, therefore, been reviewed to complete the process description.

Several routes involving conventional, commercial, or advanced technologies, which are under development, are possible. The proposed methanol production facility, based on the process suggested by Ouellette et al. [21], consists of the following basic steps (see Figure 3):

- Feedstock pre-treatment. Biomass resources most appropriate for this application include wood and wood wastes [20-22,29,30]. Feed preparation is dependent on biomass characteristics and gasifier requirement and commonly includes chipping and drying [30].

- Biomass gasification. The selection and design of any biomass gasification system are determined mainly by the characteristics of the feedstock, existing environmental legislation, the costs and performance of the equipment available, as well as the capacity needed [31]. The oxygen needed for the biomass gasification comes from water electrolysis using electricity produced from a renewable energy source. Ouellette et al. [21] indicated that an amount of10.32 ktonne of oxygen was used to gasify 10.1 ktonne of dry biomass annually. Under these conditions, all CO 
and $\mathrm{CO}_{2}$ in the syngas reacted with both electrolytic and syngas hydrogen, but oxygen was in excess. Making use of the readily available supply of electrolytic oxygen can improve the overall productivity of biomass-derived methanol $[21,25]$.

- Syngas treatment. The product gas from the gasifier contains tars, particles, dust, alkali, sulphuric and chloride compounds which can block or poison the catalysts downstream and cause corrosion of the equipment [30,32]. Generally, the smaller the molecules from which a gas is produced, the lower is the capital investment required in the treatment facilities [14]. According to Hamelinck and Faaij [30], advanced high temperature dry cleaning (see Figure 4) achieves contaminant concentrations of between 10 to 20 ppbv, sufficient to avoid catalyst contamination and damage to the equipment.

- Hydrocarbon reforming. In the presence of suitable catalysts (usually nickel based), methane, tars and other hydrocarbons are reformed into $\mathrm{CO}$ and $\mathrm{H}_{2}$ at high temperatures [30]. Both steam reforming at $830-1000^{\circ} \mathrm{C}$ and $1.0-3.5 \mathrm{MPa}$ or autothermal reforming (ATR) at $900-1000^{\circ} \mathrm{C}$ is possible.

- Hydrogen addition. The addition of hydrogen adjust the proper $\mathrm{H}_{2}: \mathrm{CO}$ ratio for methanol synthesis. This ratio should be slightly higher than $2[12,19]$. Ouellette et al. [21] reported an electrolytic hydrogen consumption of 1.29 ktonne for the production of 12.2 ktonne of methanol per year.

- Methanol synthesis. Ouellette et al. [21] chose the Lurgi methanol reactor for the conversion of the reformed syngas. The Lurgi methanol process produces methanol by catalytic conversion of synthesis gas at low pressure in the gaseous phase [14]. The main advantages of this technology are low investments and production costs, improved operational reliability, and great flexibility in the choice of the plant size [14].

- Distillation. After cooling and separation of the purge gas, the crude methanol is processed in a distillation unit to achieve the required quality.

Optional are the inclusion of a gas turbine or a boiler coupled with a steam turbine to utilise the unconverted gas for a possible electricity co-production [30].

\subsection{Performance and Economics}

In order to assess the energy conversion efficiency of the processes considered on the same basis, all energy inputs were converted into thermal energy, assuming a thermal energy-to-electricity average conversion efficiency of $38.2 \%$ [33]. The energy contents of the biomass input and the methanol produced were evaluated based on their respective Lower calorific values. A reference plant with 8000 working hours per year [25] was considered in order to compare the results of different studies. It should also be noted that these studies were carried out in different countries at different times. This might have affected the prices of raw materials as well as operation and maintenance costs. In this analysis all the prices were converted to 2005 Euros.

The evaluation of biomass-to-methanol process is based on the investigations of Ouellette et al. [21] and Specht et al. [22]. Both studies proposed two possibilities; either vent some of the $\mathrm{CO}_{2}$ produced in the gasification step, or add extra hydrogen in order to achieve the syngas composition required for the methanol synthesis. In this analysis the later option was selected to avoid $\mathrm{CO}_{2}$ emissions. Table 2 and 3 show the main results obtained from these studies. 
The figures for the electricity consumption differ so much because Specht et al. [22] considered the electricity used for the production of hydrogen by water electrolysis (i.e. $4.2 \mathrm{kWh} / \mathrm{Nm}^{3}$ of hydrogen produced) [27]. This resulted in a lower energy conversion efficiency of the process compared with the corresponding figure in the study of Ouellette et al. [21], where only the electricity required by the methanol production process was considered. This also explains the much higher capital investment for the plant proposed by Specht et al. [22] and the corresponding higher unit cost of the methanol produced.

Energy conversion efficiency of methanol production from biomass depends on three main factors:

- Additional process steps (e.g. gas cleaning and conditioning and gas compression) consume energy and decrease the overall conversion efficiency.

- Co-generation of electricity and heat can improve the efficiency.

- Energy efficiency increases with plant capacity.

Although significant progress has been achieved in biomass gasification and new improved technologies are being demonstrated, the process, with only a few rare exceptions, remains in the development stage. The main reason is that gasification of biomass to produce fuels shows lower energy conversion efficiencies and higher costs compared with the production of heat or electricity by direct biomass combustion $[34,35]$.

\section{METHANOL FROM FLUE-GASE CARBON DIOXIDE}

\subsection{Process Technology}

Using flue-gas $\mathrm{CO}_{2}$ as a feedstock to produce methanol presents the advantages of being an emission abatement technology for this greenhouse gas and recycling $\mathrm{CO}_{2}$ emitted from stationary sources as a hydrogen carrier. In this system methanol is produced by hydrogenation of $\mathrm{CO}_{2}$. This novel, but proven, technology has been studied by many authors $[3,25,27,33]$.

The three principle steps of the methanol production process are:

- $\mathrm{CO}_{2}$ separation/recovery. Amine absorption is the dominant technology for carbon dioxide extraction from flue gases. Several studies have shown it to be the most economic option for conventional pulverised coal power stations [25,27,36-38].

- $\mathrm{CO}_{2} / \mathrm{MeOH}$ transportation and storage. Once $\mathrm{CO}_{2}$ is recovered from the emitting source, it must be liquefied and transported to the hydrogen production site. Commonly, renewable electricity is available for water electrolysis in relatively remote areas, far from the methanol demand site. So also methanol might need to be transported after its production $[2,10,27,33]$.

- Methanol synthesis. The production of methanol from recycled $\mathrm{CO}_{2}$ and $\mathrm{H}_{2}$ consists of two steps: methanol synthesis (or $\mathrm{CO}_{2}$ hydrogenation) over a catalyst and methanol purification $[25,33,38,39]$. However, prior to entering the synthesis reactor, the gases may need some conditioning. 


\subsection{Performance and Economics}

The evaluation of $\mathrm{CO}_{2}$-to-methanol process has been based on the investigations of Mignard et al. [25], Specht et al. [27] and Sakamoto and Zhou [33]. Energy losses, high capital costs and the energy needed to liquefy hydrogen makes the option of transporting electrolytic hydrogen to the methanol generation plant economically unviable. Therefore, two possible practical scenarios can be adopted in the production of methanol from carbon dioxide:

- Scenario A: Transport the $\mathrm{CO}_{2}$ to the hydrogen production site. The costs and energy consumption of transporting both carbon dioxide, captured from the flue gases of coal-fired power stations, and methanol to and from the hydrogen production plant, respectively, were assessed by Specht et al. [27] and Sakamoto and Zhou [33]. The methanol plant proposed by Sakamoto and Zhou [33] consists of two major facilities, the $\mathrm{MeOH}$ synthesis unit and a fuel cell unit, and produces 323 tonne/hour (2.58 Mtonne/year) of $\mathrm{MeOH}$. Specht et al. [27] based their studies on methanol synthesis using a bench-scale plant with an assumed capacity of 200 tonnes per day. Results from both studies are given in Table 4. The higher energy conversion efficiency of the system proposed by Sakamoto and Zhou [33] is due the higher capacity of the methanol plant, which is more than 38 times the capacity of the plant suggested by Specht et al. [27], and the lower overall energy consumption, principally due to the lower energy consumption in the $\mathrm{CO}_{2}$ recovery process. Furthermore, Specht et al. [27] did not take into account the energy needed in the form of heat in the methanol process, so the actual efficiency of his process is slightly overestimated. This scenario entails the difficulty of providing the heat necessary for methanol distillation units, i.e. $9.83 \mathrm{kWh} / \mathrm{kmol}$ of feed gas [38]. This amount of heat cannot be satisfied by the heat available from the methanol synthesis reaction, i.e. $2.01 \mathrm{kWh} / \mathrm{kmol}$ of feed gas [38]. To supply the remaining heat required, a small-scale, efficient biomass combustion unit can be employed.

- Scenario $\mathrm{B}$ : The $\mathrm{CO}_{2}$ recovery site is very close to the electrolysis plant. The results of Mignard et al. [25] for this study are summarised in Table 5. In addition to the advantage of cost savings in processing, shipping and delivering the captured $\mathrm{CO}_{2}$, there is also the possibility of making use of the waste heat from the power station [25]. This avoids the production of steam to supply the methanol plant, and thus eliminates any additional $\mathrm{CO}_{2}$ emissions. However, the limitation of this scenario is that renewable energy utilisation schemes are commonly located in remote locations, where they are more viable, far away from the power stations from which the $\mathrm{CO}_{2}$ is recovered.

Table 6 presents a comparison of available data concerning the economics of the processes investigated for scenarios $A$ and $B$. The unit production cost of methanol depends strongly on the unit price of renewable electricity (assumed to be hydroelectricity) used for hydrogen production by the electrolysis of water. The huge difference in capital cost, reported by Mignard et al. [25], compared with those for biomass processes is due to the inclusion of the extra units for the flue gas cleaning, water purification plant for the electrolyser and a fuel cell plant to supply electricity when renewable energy is not available.

For the production of methanol, the amount of $\mathrm{CO}_{2}$ recovered from the flue gases must be matched with electrolytic hydrogen with a 1:3 molal ratio. The hydrogen production will be usually limited to electricity off-peak periods. Therefore, the capacity of the methanol plant will depend on the amount of renewable electricity committed for this purpose. Specht et al. [27] suggested that the efficiency of the entire process can be improved if more efficient $\mathrm{CO}_{2}$ recovery systems are employed. Commercially-available 
catalysts employed in $\mathrm{CO}_{2}$ hydrogenation loose activity and selectivity. New catalysts for this process are currently under investigation.

\section{CONCLUSIONS}

Excess generation capacity of renewable energy utilisation schemes at off-peak periods can be used for hydrogen production by electrolysis. Currently hydrogen has a limited use as a fuel. Utilising this hydrogen for the production of methanol results in a more friendly fuel, ready to use within the current infrastructure.

Because of their independence of fossil fuels and environmental advantages, two possible pathways of producing renewable methanol using electrolytic hydrogen have been investigated (see Figure 5): methanol production by the synthesis of the syngas resulting from biomass gasification, and by hydrogenation of carbon dioxide captured from the flue gases of mainly coal-fired power stations.

Methanol production from biomass has been proved cheaper and more efficient than from $\mathrm{CO}_{2}$ (see Table 7). It can, therefore, be considered as a realistic, short-term option of producing methanol from renewable hydrogen. On the other hand, methanol production from carbon dioxide must be also seen as a way of the abatement of the emissions of this greenhouse gas and reduce its emissions. Although many options are being investigated for the utilisation of $\mathrm{CO}_{2}$ captured from flue gases of power stations, methanol production has been demonstrated to be a feasible alternative option. Further advances in $\mathrm{CO}_{2}$ recovery technology, make this option a viable long-term proposition for renewable methanol production.

\section{REFERENCES}

[1] IEA (International Energy Agency). Renewables for Power Generation: Status and Prospects. Paris, France: IEA/OECD; 2003. Available at: www.iea.org; August 2005.

[2] Hiraoka K. Prospects for a hydrogen-solar energy system. Translated from J Middle Eastern Studies 2001; 35(9). Available at: www.mesj.or.jp/mesj_e/english/pub/ english/pdf/mv29n022001p71.pdf; August 2005.

[3] Duthie JM and Whittington HW. Securing renewable energy supplies through carbon dioxide storage in methanol. In: Proceedings of the IEEE power engineering summer meeting, July 21-25, Chicago, USA, 2002; 1:145-150.

[4] Schulien S, Sandstede G, and Hahn HW. Hydrogen and carbon dioxide as raw materials for an ecological energy-technology. International J Hydrogen Energy 1999; 24:299-303.

[5] Wolf BM. Bio-methanol as a fuel available from regional sources. In: Proceedings of EUROSOLAR conference on promoting global transfer activities for renewable energies, June 8-10 2001, Berlin, Germany. Bonn, Germany: EUROSOLAR- Verlag; 2002. 
[6] Specht M, Staiss F, Bandi A and Weimer T. Comparison of the renewable transportation fuels, liquid hydrogen and methanol, with gasoline - energetic and economic aspects. International J Hydrogen Energy 1997; 23(5):387-396.

[7] EPA (US Environmental Protection Agency). Methanol basics. Technical Report EPA 400-F-92-009. Washington DC, USA: EPA; 1994. Available at: www.epa.gov; April 2005.

[8] EPA (US Environmental Protection Agency). Clean alternative fuels: Methanol. Technical Report EPA 420-F-00-040. Washington DC, USA: EPA; 2002. Available at: www.epa.gov; July 2005.

[9] Hemmings JW and Todd DM. The Starchem methanol process: A low cost route to methanol and power. New Jersey, USA: Foster Wheeler International Corporation. Available at: www.fwc.com/publications/tech_papers/oil_gas/starchem1.cfm; July 2005.

[10] Fiedler E, Grossmann G, Kersebohm DB, Weiss G and Witte C. Methanol. In: Ullmann's encyclopedia of industrial chemistry, $7^{\text {th }}$ ed. Weinheim, Germany: Wiley-VCH Verlag GmbH \& Co.; 2005.

[11] Spath PL and Dayton DC. Preliminary screening - technical and economic assessment of synthesis gas to fuels and chemicals with emphasis on the potential for biomassderived syngas. Technical Report NREL/TP-510-34929. Colorado, USA: NREL (National Renewable Energy Laboratory), DOE (US Department of Energy); 2003.

[12] Roan V, Betts D, Twining A, Dinh K, Wassink P and Simmons T. An investigation of the feasibility of coal-based methanol for application in transportation fuel cell systems. Report. USA: University of Florida; 2004.

[13] Hugill JA, Overbeek JP and Spoelstra S. A comparison of the eco-efficiency of two production routes for methanol. Report ECN-I-01-003. The Netherlands: ECN (Energy Research Centre of the Netherlands); 2001.

[14] Rauch R. Biomass gasification to produce synthesis gas for fuel cells, liquid fuels and chemicals. Technology brief. IEA Bioenergy agreement, Task 33: Thermal gasification of biomass (2001-2003); 2002. Available at: www.gastechnology.org/ webroot/downloads/en/IEA/TechnologybriefSynthesisGas.pdf; January 2005.

[15] Synetix. Synetix low pressure methanol (LPM) process. Cleveland, USA: Synetix. Available at: www.synetix.com; January 2005.

[16] Williams RH, Larson ED, Katofsky RE and Chen J. Methanol and hydrogen from biomass for transportation. Energy for Sustainable Development 1995; 1(5):18-34.

[17] Clean Coal Technology Programme. Commercial scale demonstration of the liquid phase methanol (LPMEOH) process. Topical Report 11. USA: Clean Coal Technology Programme, US Department of Energy (DOE). Office of Fossil Energy; 1999. Available at: www.fe.doe.gov; January 2005.

[18] DOE (US Department of Energy). Commercial-scale demonstration of the liquid phase methanol (LPMEOH) process. Report No.DOE/NETL-2004/1199. Washington DC; USA: Office of Fossil Energy, DOE; 2003.

[19] Specht $M$ and Bandi A. The Methanol cycle - sustainable supply of liquid fuels. Stuttgart, Germany: Centre for Solar Energy and Hydrogen Research (ZSW); 1999. Available at: www.zsw-bw.de; January 2005.

[20] DOE (US Department of Energy). Assessment of costs and benefits of flexible and alternative fuel use in the US transportation sector; technical report 5: costs of methanol production from biomass. Report No. DOE/PE-0097P. Washington DC, USA: Office of Policy, Planning and Analysis, DOE; 1990.

[21] Oullette N, Rogner HH and Scott DS. Hydrogen from remote excess hydroelectricity. Part II: Hydrogen peroxide or biomethanol. International J Hydrogen Energy 1995; 20(11):873-880. 
[22] Specht M, Bandi A, Baumgart F, Murray CN and Gretz J. Synthesis of methanol from biomass $/ \mathrm{CO}_{2}$ resources. In: Eliasson $\mathrm{B}$, Riemer PWF and Wokan $\mathrm{A}$, editors. Proceedings of the $4^{\text {th }}$ international conference on greenhouse gas control technologies, 30 August-2 September. Amsterdam, The Netherlands: Pergamon; 1998: 723-728.

[23] Saito M, Takeuchi M, Fujitani T, Toyir J, Luo S, Wu J, Mabuse H, Ushikoshi K, Mori K and Watanabe T. Advances in joint research between NIRE and RITE for developing a novel technology for methanol synthesis from $\mathrm{CO}_{2}$ and $\mathrm{H}_{2}$. Applied Organometallic Chemistry 2000; 14:763-772.

[24] Stucki S, Schuler A and Constantinescu M. Coupled $\mathrm{CO}_{2}$ recovery from the atmosphere and water electrolysis: Feasibility of a new process for hydrogen storage. International J Hydrogen Energy 1995; 20(8):653-663.

[25] Mignard D, Sahibzada M, Duthie JM and Whittington HW. Methanol synthesis from fluegas $\mathrm{CO}_{2}$ and renewable electricity: A feasibility study. International J Hydrogen Energy 2003; 28:455-464.

[26] Larson ED and Tingjing R. Synthetic fuel production by indirect coal liquefaction. Energy for Sustainable Development 2003; 7(4):79-102.

[27] Specht $\mathrm{M}$, Bandi $\mathrm{A}$, Elser $\mathrm{M}$ and Staiss $\mathrm{F}$. Comparison of $\mathrm{CO}_{2}$ sources for the synthesis of renewable methanol. In: Inui T, Anpo M, Izui K, Yanagida S and Yamaguchi T, editors. Advances in chemical conversions for mitigating carbon dioxide. Amsterdam, The Netherlands: Elsevier; 1998: 363-367.

[28] Eliasson B. $\mathrm{CO}_{2}$ chemistry: An option for $\mathrm{CO}_{2}$ emission control? In: Pradier JP and Pradier CM, editors. Carbon dioxide chemistry: Environmental issues. Cambridge, UK: The Royal Society of Chemistry; 1994: 5-15.

[29] Woods $\mathrm{J}$ and Bauen A. Technology status review and carbon abatement potential of renewable transport fuels in UK. Report No. B/U2/00785/REP. London, UK: DTI (UK Department of Trade and Industry) new and renewable energy programme. DTI; 2003.

[30] Hamelinck CN and Faaij AP. Future prospects for production of methanol and hydrogen from biomass. Report NWS-E-2001-49. The Netherlands: Utrecht University; 2001.

[31] IEA Bioenergy. Biomass combustion and co-firing: An overview. IEA Bioenergy, Task 32; 2002. Available at: www.ieabcc.nl; July 2005.

[32] Ciferno JP and Marano JJ.. Benchmarking biomass gasification technologies for fuels, chemicals and hydrogen production. USA: NETT, US Department of Energy (DOE); 2002.

[33] Sakamoto $\mathrm{Y}$ and Zhou W. Energy analysis of a $\mathrm{CO}_{2}$ recycling system. International $\mathrm{J}$ Energy Research 2000; 24:549-559.

[34] EUBIA (European Biomass Industry Association), Brussels. www.eubia.org; July 2005.

[35] Specht M, Zuberbühler $U$ and Bandi A. Why biofuels? An introduction to the topic. Stuttgart, Germany: Centre for Solar Energy and Hydrogen Research (ZSW), (Unpublished Report); 2005.

[36] Rubin E and Rao A. Technical, economic and environmental assessment of aminebased $\mathrm{CO}_{2}$ capture technology for power plant greenhouse gas control. West Virginia, USA: DOE (US Department of Energy); 2002.

[37] Dyer G. Review and assessment of carbon dioxide emissions mitigation technologies. MSc Thesis. UK: School of Engineering. Cranfield University; 2004.

[38] Pritchard $\mathrm{CL}$ and Mignard D. Squaring the circle: Sequestration of $\mathrm{CO}_{2}$ as liquid fuel. Paper presented at GHGT-7, Internacional conference on greenhouse gas control technologies, September 5-9, Montreal, Canada; 2004.

[39] Lachowska M and Skrzypek J. Methanol synthesis from carbon dioxide and hydrogen over Mn-promoted copper/zinc/zirconia catalysts. Reaction Kinetics and Catalysis Letters 2004; 83(2):269-273. 
[40] Sakamoto $\mathrm{Y}$, Zhou W and Kawabe T. Performance analysis of a $\mathrm{CO}_{2}$ recycling system which utilizes solar energy. International J Energy Research 2001; 25:275-280.

\section{Figure captions}

Figure 1. Flow diagram for methanol production from $\mathrm{CO}_{2}$

Figure 2. Estimated methanol production costs for different concepts of methanol synthesis

Figure 3. Key components in biomass to methanol production facility

Figure 4. Hot Gas cleaning [30]

Figure 5. Pathways for the production of renewable methanol 


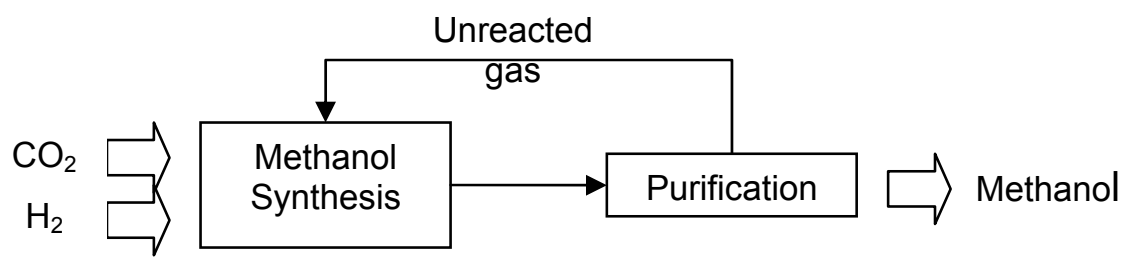

Figure1

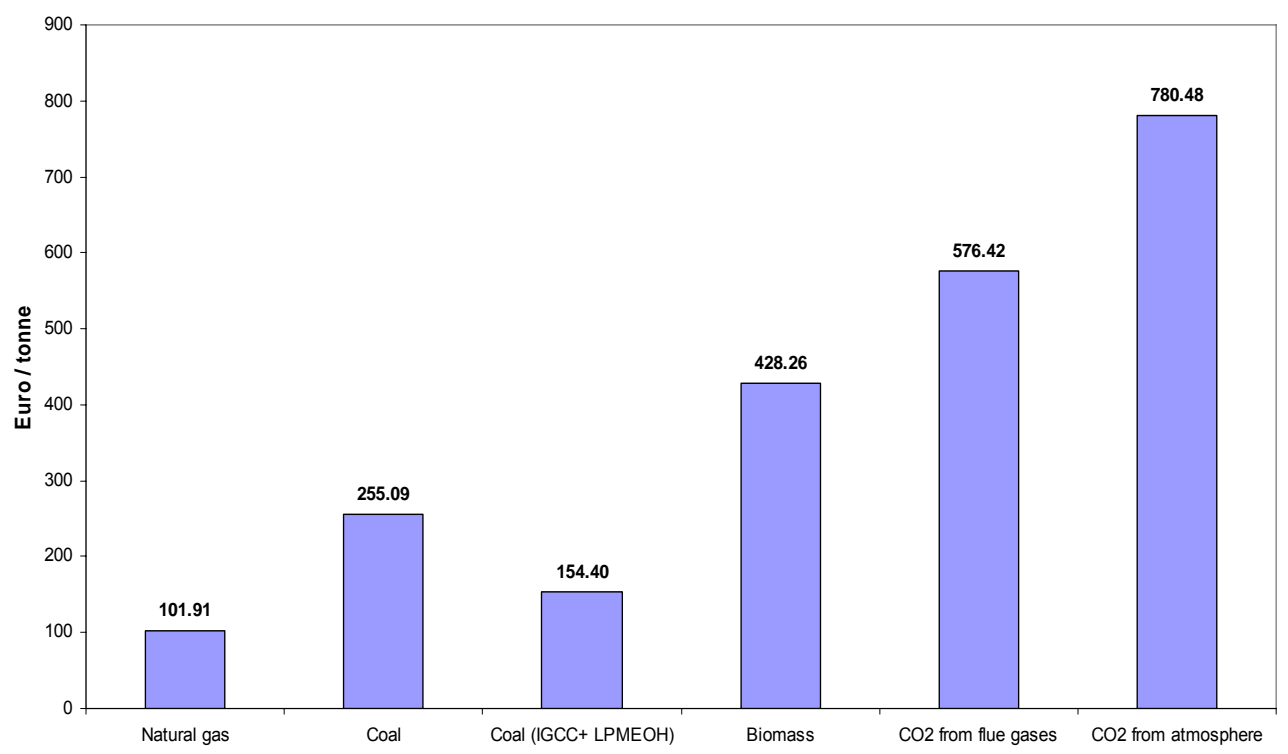

Figure 2 


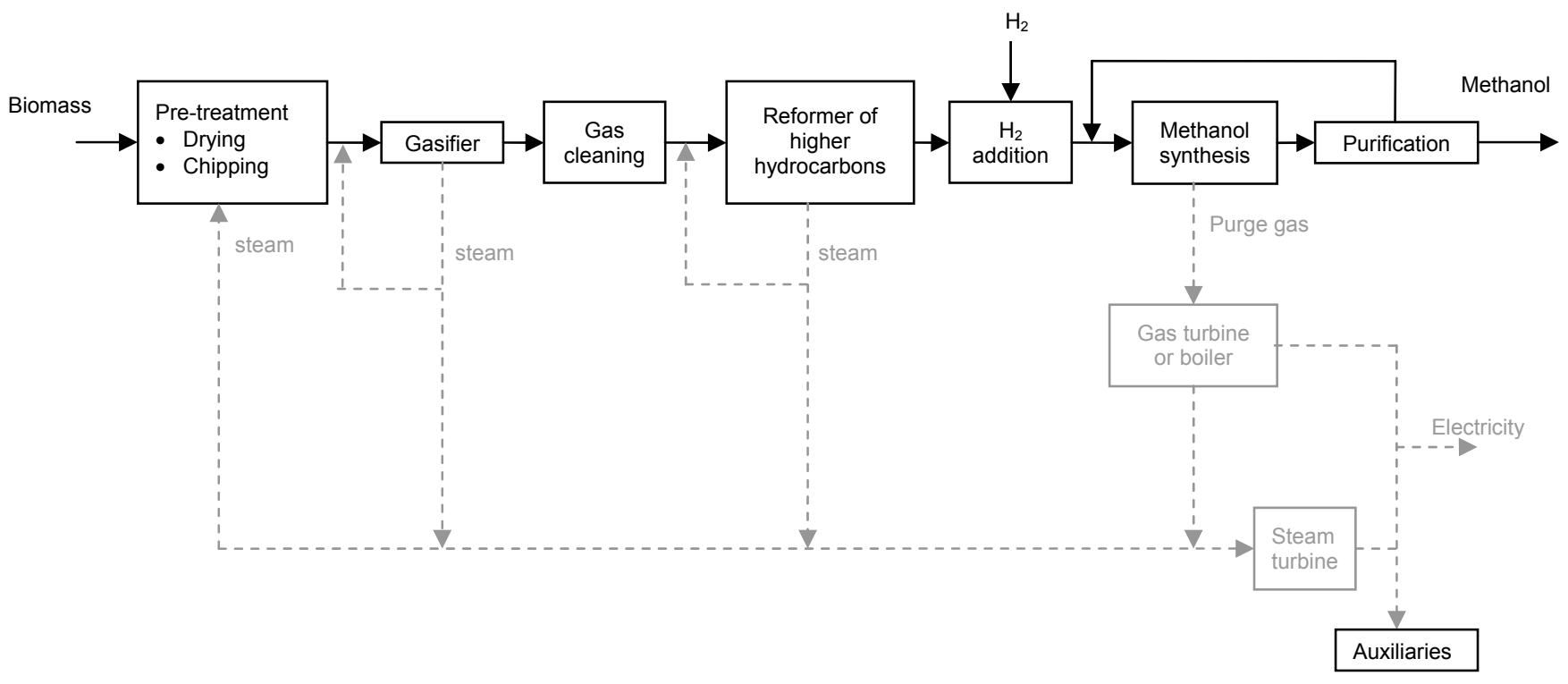

Figure 3

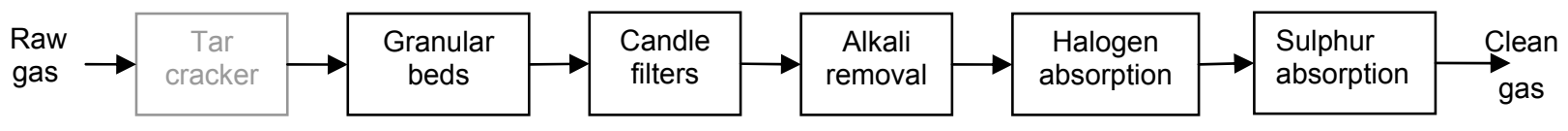

Figure 4 


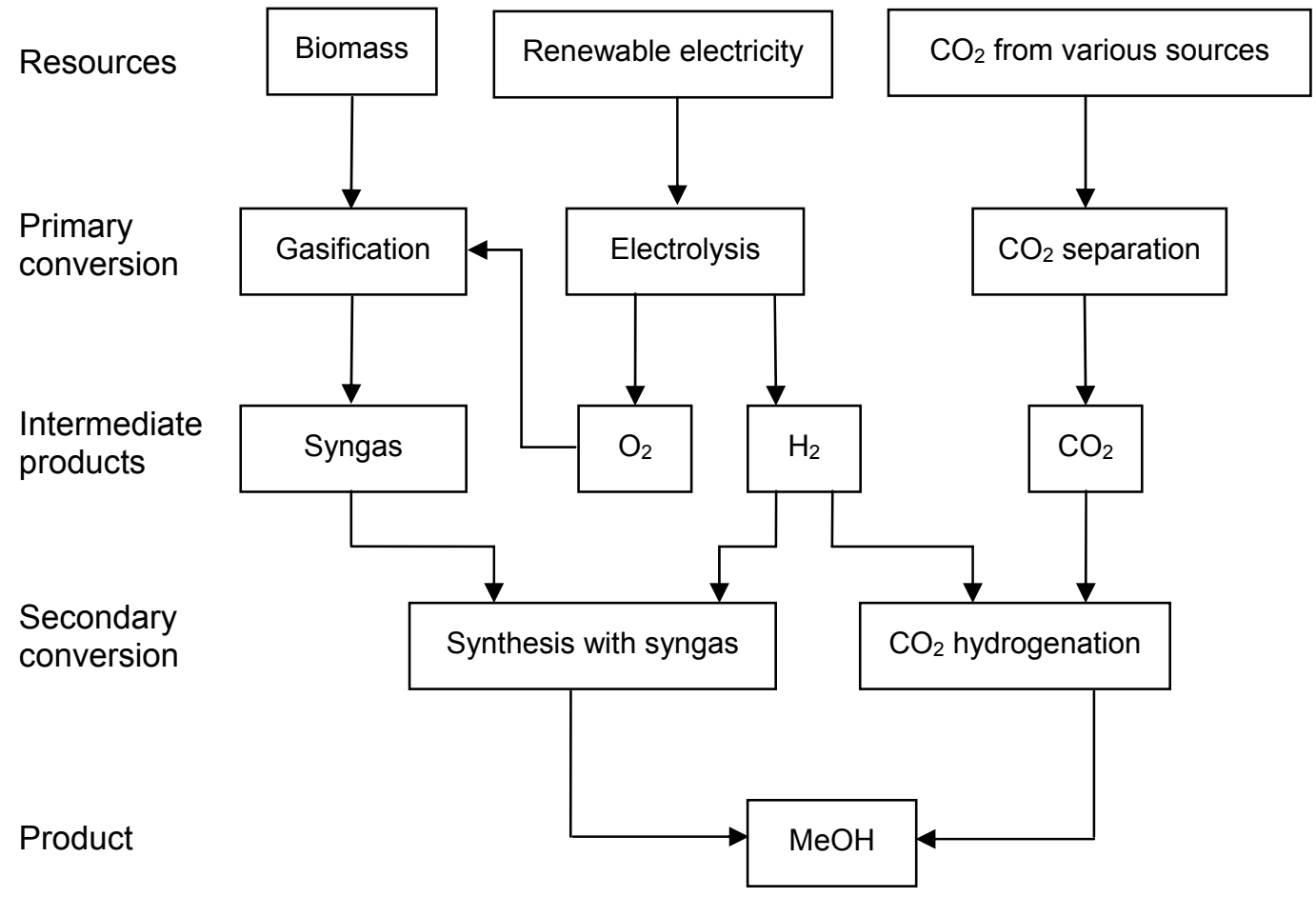

Figure 5 
Table 1. Methanol technology suppliers [11]

\begin{tabular}{|c|c|c|c|}
\hline $\begin{array}{l}\text { Technology } \\
\text { supplier }\end{array}$ & $\begin{array}{l}\text { Temperature } \\
\left({ }^{\circ} \mathrm{C}\right)\end{array}$ & $\begin{array}{l}\text { Pressure } \\
\quad \text { (bar) }\end{array}$ & Notes \\
\hline ICl (Synetix) & $210-290$ & $50-100$ & $\begin{array}{l}\text { Currently licenses } 4 \text { types of reactors: ARC, } \\
\text { Tubular Cooled, Isothermal Linde, and Toyo }\end{array}$ \\
\hline Lurgi & $230-265$ & $50-100$ & Tubular, isothermal reactor \\
\hline Mitsubishi & 240 & $77-97$ & Tubular, isothermal reactor \\
\hline Kellogg & & & Spherical reactor geometry \\
\hline Haldor-Topsoe & 260 & $48-300$ & $\begin{array}{l}\text { To date, no commercial plants based on this } \\
\text { process }\end{array}$ \\
\hline
\end{tabular}

Table 2. Performance comparison of biomass-to-methanol processes

\begin{tabular}{lcc}
\hline & Ouellette et al. [21] & Specht et al. [22] \\
\hline Biomass consumption (dry ktonne/year) & 10.10 & 14.40 \\
Electricity consumption (MWh/tonne MeOH) & 0.32 & 6.68 \\
MeOH production (ktonne/year) & 12.21 & 17.60 \\
Energy conversion efficiency (\%) & 44.00 & 25.63 \\
\hline
\end{tabular}

Table 3. Economic comparison of biomass-to-methanol processes

\begin{tabular}{lcc}
\hline & Ouellette et al. [21] & Specht et al. [22] \\
\hline Capital investment $\left(10^{6} €\right)$ & 10.76 & 23.93 \\
Unit cost of electricity $(€ / \mathrm{kWh})$ & 0.01 & 0.03 \\
Unit cost of $\mathrm{MeOH}$ production $(€ /$ tonne $)$ & 348.47 & 428.26 \\
\hline
\end{tabular}

Table 4. Performance comparison of $\mathrm{CO}_{2}$-to-methanol processes (Scenario A)

\begin{tabular}{lcc}
\hline & Specht et al. [27] & Sakamoto and Zhou [33] \\
\hline MeOH production (ktonne/year) & 66.66 & 2580 \\
Total electricity consumption (MWh/tonne MeOH) & 12.03 & 10 \\
\hline
\end{tabular}




\begin{tabular}{|c|c|c|c|}
\hline \multicolumn{2}{|c|}{ Energy conversion Efficiency (\%) } & 17.6 & 21 \\
\hline \multicolumn{2}{|c|}{$\mathrm{CO}_{2}$ emissions (tonne $\mathrm{CO}_{2} /$ tonne $\mathrm{MeOH}$ ) } & $0.8^{\mathrm{a}}$ & 0 \\
\hline \multicolumn{4}{|c|}{$\begin{array}{l}\text { a according to Specht and Bandi [19] } \\
\text { b according to Sakamoto et al. [40] }\end{array}$} \\
\hline & \multicolumn{3}{|c|}{ Table 5. Performance of $\mathrm{CO}_{2}$-to-methanol processes (Scenario B) [25] } \\
\hline & \multicolumn{2}{|l|}{$\mathrm{MeOH}$ production (ktonne/year) } & 3.84 \\
\hline & \multicolumn{2}{|c|}{ Heat $\left(>120^{\circ} \mathrm{C}\right)$ consumption $(\mathrm{MWh} /$ tonne $\mathrm{MeOH})$} & 2.34 \\
\hline & \multicolumn{2}{|c|}{ Total electricity consumption (MWh/tonne $\mathrm{MeOH})$} & 9.15 \\
\hline & \multirow{2}{*}{ Energy conversion efficiency (\%) } & Waste heat scenario & 23 \\
\hline & & Process steam scenario & 18.4 \\
\hline
\end{tabular}

Table 6. Economic comparison of $\mathrm{CO}_{2}$-to-methanol processes

\begin{tabular}{lcc}
\hline & Mignard et al. [25] & Specht et al. [27] \\
\hline Capital investment $\left(10^{6} €\right)$ & 158.29 & $\mathrm{n} / \mathrm{a}$ \\
Unit cost of electricity $(€ / \mathrm{kWh})$ & $0.022^{\mathrm{a}}$ & 0.03 \\
$\mathrm{MeOH}$ unit production cost $(€ /$ tonne $)$ & $0.015^{\mathrm{b}}$ & 579.75 \\
\hline a Peak renewable electricity & $\mathrm{n} / \mathrm{a}$ & \\
b Off-peak renewable electricity & &
\end{tabular}

Table 7. Biomass vs. $\mathrm{CO}_{2}$ for methanol production

\begin{tabular}{lcc}
\hline & $\begin{array}{c}\mathrm{MeOH} \text { from } \\
\text { Biomass }\end{array}$ & $\begin{array}{c}\mathrm{MeOH}^{\mathrm{CO}} \text { from } \\
\mathrm{CO}_{2}\end{array}$ \\
\hline Electricity consumption (MWh/tonne $\mathrm{MeOH})$ & $0.32-7$ & $9-12$ \\
Energy conversion efficiency $(\%)$ & $25-44$ & $17-23$ \\
Capital investment (million $€$ ) & $10-24$ & 158 \\
$\mathrm{MeOH}$ unit production cost $(€ /$ tonne) & $300-400$ & $500-600$ \\
\hline
\end{tabular}

